\title{
ACRL Nominees for Offices, 1975/76
}

\section{VICE-PRESIDENT/PRESIDENT-ELECT}

Connie R. Dunlap, Head Librarian, Graduate Library, University of Michigan, Ann Arbor, Michigan

H. Joanne Harrar, Associate Director of Libraries, University of Georgia, Athens, Georgia

\section{AGRICULTURE AND BIOLOGICAL SCIENCES SECTION}

Vice-Chairman/Chairman-Elect

Elisabeth B. Davis, Biology Librarian, University of Illinois, Urbana, Illinois

Barbara B. Gordon, Forest Resources Librarian, University of Washington, Seattle, Washington

Secretary

Arne K. Richards, Documents Librarian, Kansas State University, Manhattan, Kansas

Eris E. Roth, Head, Technical Services, U.S. Social Security Administration Library, Baltimore, Maryland

\section{ANTHROPOLOGY SECTION}

\section{Vice-Chairman/Chairman-Elect}

To be nominated

Secretary

Patrick Ashley, Head, Search Department, Northwestern University Library, Evanston, Illinois

Suzy M. Slavin, Assistant Head, Reference Department, McGill University Library, Montreal, Quebec, Canada

Member-at-Large

Ruth L. Opler, Assistant Librarian, Health Sciences Library, State University of New York at Buffalo, Buffalo, New York

Patricia Ann White, Reference Librarian, Michigan State University, East Lansing, Michigan

\section{ART SECTION}

Vice-Chairman/Chairman-Elect

Mary Ashe, Art and Music Librarian, San Francisco Public Library, San Francisco, California

Rosella L. Ferster, Art Cataloger, Duke University Library, Durham, North Carolina

Secretary

Stephanie Frantz, Art Librarian, University of Rochester, Rochester, New York

Barbara E. Reed, Assistant Art Librarian, State University of New York at Buffalo, Buffalo, New York

\section{ASIAN AND AFRICAN SECTION}

Vice-Chairman/Chairman-Elect

Charles R. Bryant, Curator, Southeast Asia
Collection, Yale University Library, New Haven, Connecticut

John A. Eilts, Near East Bibliographer, University of Michigan Library, Ann Arbor, Michigan

Member-at-Large

Karl K. Lo, Head Librarian, Asiatic Collection, University of Washington, Seattle, Washington

Jack A. Siggins, Director, East Asia Collection, University of Maryland, College Park, Maryland

\section{COLLEGE LIBRARIES SECTION}

\section{Vice-Chairman/Chairman-Elect}

Melvin R. George, Director of the Library, Northeastern Illinois University, Chicago, Illinois

Marjorie H. Sibley, Head Librarian, Augsburg College, Minneapolis, Minnesota

Secretary

Edmund R. Arnold, Director of Library Services, Cornell College, Mount Vernon, Iowa

James F. Parks, Jr., Head Librarian, Millsaps

College, Jackson, Mississippi

\section{COMMUNITY AND JUNIOR COLLEGE LIBRARIES SECTION}

\section{Vice-Chairman/Chairman-Elect}

Ambrose Easterly, Director of Library Services, Harper College, Palatine, Illinois

Jo Ellen Flagg, Librarian, Forest Park Community College, St. Louis, Missouri

Secretary

Stanley N. Ruckman, Head Librarian, LinnBenton Community College, Albany, Oregon

Robert F. Schremser, Librarian, Alexander City State Junior College, Alexander City, Alabama

\section{EDUCATION AND BEHAVIORAL SCIENCES SECTION}

\section{Vice-Chairman/Chairman-Elect}

Ruth Bauner, Education/Psychology Librarian, Southern Illinois University, Carbondale, Illinois

Margaret Perry, Head Librarian, Education Library, University of Rochester, Rochester, New York

Secretary

Robert Baumruk, Chief, Social Sciences and Business Department, Chicago Public Library, Chicago, Illinois

Eva L. Kiewitt, Librarian, Graduate Library School, Indiana University, Bloomington, Indiana 


\section{LAW AND POLITICAL \\ SCIENCE SECTION}

Vice-Chairman/Chairman-Elect

Oleg Kudryk, Head, Acquisitions Department, Indiana University Libraries, Bloomington, Indiana

Catherine A. Porter, Librarian, Vinson, Elkins, Searls, Connally \& Smith (Attorneys at Law ), Houston, Texas

Member-at-Large

To be nominated

\section{RARE BOOKS AND MANUSCRIPTS SECTION}

Vice-Chairman/Chairman-Elect

J. William Matheson, Chief Librarian, Rare Book Division, Library of Congress, Washington, D.C.

Clyde C. Walton, Director of Libraries, Northern Illinois University, DeKalb, Illinois

Secretary

Shirley B. Lebo, Principal Evaluations Officer, Library of Congress, Washington, D.C.

N. Frederick Nash, Rare Book Room Librarian, University of Illinois, Urbana, Illinois

Member-at-Large

Vesta Lee Gordon, Assistant Curator for Technical Services, Manuscripts Department, Alderman Library, University of Virginia, Charlottesville, Virginia

J. Richard Phillips, Special Collections Li- brarian, Amherst College, Amherst, Massachusetts

\section{SLAVIC AND \\ EAST EUROPEAN SECTION}

Vice-Chairman/Chairman-Elect

George C. Jerkovich, Head, Slavic Department, University of Kansas Libraries, Lawrence, Kansas

Oleg Kudryk, Head, Acquisitions Department, Indiana University Libraries, Bloomington, Indiana

Secretary

Christopher J. Guleff, Special Services Librarian, Indiana State University, Terre Haute, Indiana

Benedict Markowski, Head, Foreign Language Collection, Detroit Public Library, Detroit, Michigan

Member-at-Large

Gordana Rezab, Assistant Acquisitions Librarian, Western Illinois University, Macomb, Illinois

Eryk Talat-Kielpsz, Senior Slavic Cataloger, Ohio State University Library, Columbus, Ohio

\section{UNIVERSITY LIBRARIES SECTION}

Vice-Chairman/Chairman-Elect

C. James Schmidt, Director of Libraries, State University of New York at Albany, Albany, New York

James K. Zink, Director of Libraries, University of Oklahoma, Norman, Oklahoma

\section{ACRL Chapter News}

The Illinois Association of College and Research Libraries at its fall meeting, October 25, 1974, in Springfield, announced the results of its recent elections. Officers of the chapter for 1974/75 are: Clyde C. Walton, director of libraries at Northern Illinois University, DeKalb, chairman; Imogene I. Book, librarian at Rend Lake College, Ina, vice-chairman; and Robert $\mathrm{N}$. Broadus, professor of library science at

\section{SLIP.ON BOOK JACKETS \\ OF CLEAR PLASTIC BOOK PAL。 \\ pal enterprises \\ 4646 gravois \\ st. louis, mo. 63116 \\ (314) $481-2779$}

Protective

Attractive

Long-lasting
Northern Illinois University, secretary. The editor of the chapter's new publication, the IACRL Newsletter, is Herbert Biblo, head of reader services at the John Crerar Library.

ACRL's Minnesota chapter, the Academic and Research Division of the Minnesota Library Association, has also announced new officers for 1974/75: Virgil F. Massman, executive director of the James J. Hill Reference Library, St. Paul, chairman; Rosalie Bunge, librarian at Normandale Community College, Bloomington, chairman-elect; and Karen Fischer, librarian at the College of St. Benedict, St. Joseph, secretary/treasurer. Lawrence R. Cullen, librarian at North Hennepin Community College, Minneapolis, is serving as editor for the chapter and is responsible for submitting news items for publication in the Minnesota Library Association newsletter and journal. 